International Journal of Linguistics, Literature and Culture
Available online at https://sloap.org/journals/index.php/ijllc/
Vol. 4, No. 5, September 2018, pages: $20 \sim 30$
ISSN: 2455-8028
https://sloap.org/journals/index.php/ijllc/article/view/289

\title{
The Black Community Portrayal in Toni Morrison's The Bluest Eye (1970), Sula (1973) and Song of Solomon (1977)
}

Ferdinand Kpohoue a

Article history:

Received: 10 April 2018

Accepted: 30 August 2018

Published: 20 September 2018

\section{Keywords:}

Black community;

Novel;

Setting;

Toni Morrison;

White society;

\begin{abstract}
This paper aims at investigating Toni Morrison's endeavor to locate the black community's actions in three of her novels: The Bluest Eye (1970), Sula (1973), and Song of Solomon (1977). Toni Morrison's novels have particularly depicted the black community from a specific perspective, the one that is largely defined and shared by the dominant white society and its standards. The Bluest Eye sets in Morrison's hometown, Lorain, Ohio. In this novel, the black community in Lorain is separated from the upper-class white community, also known as Lake Shore Park, a place where blacks are not permitted. As for Sula the setting is a small town in Ohio, located on a hillside known as "Bottom". Song of Solomon plunges the reader into the absorbing black community, a standalone entity, but yet never far removed from the white world. The first pages of the novel describe "Not Doctor Street" and "No Mercy Hospital". These names are used within the AfricanAmerican community but are unofficial and not recognized by the white city rulers who instead identify them as Mains Avenue and Mercy Hospital. In short, the setting for Song of Solomon is an anonymous city in Michigan, Pennsylvania, and Virginia. The study has revealed that there always exists a white community bordering the black community as its standard and a machine to repress and exploit its people. This parallel which is actually a quest for identity is omnipresent in Morrison's novels surely because she is an African American writer.
\end{abstract}

2455-8028 ${ }^{\circledR}$ Copyright 2018. The Author. This is an open-access article under the CC BY-SA license (https://creativecommons.org/licenses/by-sa/4.0/) All rights reserved.

\section{Author correspondence:}

Ferdinand Kpohoue,

Department of English, American Studies Program,

Faculty of Letters, Languages, Arts, and Communication (FLLAC),

University of Abomey-Calavi (UAC), Benin Republic

Email address: ferdinandkpo@yahoo.fr

${ }^{a}$ University of Abomey-Calavi (UAC), Benin Republic 


\section{Introduction}

Toni Morrison (1987), is the first black female writer to have won and been awarded the Nobel Prize of literature in 1993. As far as the settings of her three first novels are concerned, it is important to correlate them back to her origin. Toni Morrison was born Chloe Anthony Wofford, daughter of Ramah Willis and George Wofford, in Lorain, Ohio. Morrison's grandfather, a worker in the coal mines, fleed from the poverty and racism prevailing in Greenville and Birmingham to settle and establish her family in Ohio. Her father, George Wofford, comes from Georgia, a violent racial state that had an impact on his vision of white America. It is with him that Morrison gets "a strong sense of her own value on her own terms" (McKay, 1993, p.414), and this sense of value helps to shape Morrison's way of writing about African-American people. Her novels, especially the first three novels, are set in her hometown and in Africa through the mythical Song of Solomon. In short, the black community is the very place where characters take actions. This focus is a way to draw attention on the blacks and their conditions in America where racial discrimination is a reality. The black communities in her novels are the suburbs of white bordering communities that pressurize them. Song of Solomon has referred to a myth to consider a possibility for the blacks to escape the racially discriminated America to join their kinsmen in Africa. This paper has undertaken to analyze the very motives and impacts of Toni Morrison (1993), a technique to use the black community as setting in her novels. Interactions between both communities have revealed the existence of two social groups living side by side but different, unequal: the black community is belittled, exploited, and hated by the black community.

\section{Materials and Methods}

The ongoing research work has considered and applied the qualitative research method to the three novels under study. It proceeds through a critical reading of the Toni Morrison's three novels serving as the backbone for the literary reasoning. This paper considers a hypothesis, the one assuming the societal gap existing and always deepening between the two communities at stake in fiction (Morrison, 2004). Thereafter, a comparative critical discussion has been carried out all over the three corpora in order to appraise the gist of the idea put forth by Morrison in her enticing and exiting fiction. The intuitive data collection is carried out throughout the three novels with sequences portraying of the Black Community as opposed to the White Community in the fiction. In so doing, the qualitative research paradigm enables here to draw a parallel between the two cohabitating communities and substantiate the quest for true identity which is omnipresent in novels (Morrison, 1987). This has been fully accounted for an exemplified development through appropriate quotes referenced from the novels under consideration.

\section{Results and Discussions}

\subsection{Overview of the first three novels written by Toni Morrison: The Bluest Eye (1970), Sula (1973), Song of Solomon (1977)}

Toni Morrison is a prolific and famous writer. Her first three novels are the focus of this study. Therefore, I find it necessary to overview them in order to display the diversity of the ideas developed in each novel before focusing on their similarity in terms of settings.

In The Bluest Eye, Morrison (1973), examined beauty and value from the perspective of the black community and how black society imposes an incongruous white standard on its constituents. Pecola Breedlove is a young African American girl coming of age during the 1940s. She longs to be loved and accepted by her own community as well as in a world which rejects and diminishes the value of the members of her own race and defines beauty according to an Anglo Saxon cultural standard. Pecola's desire manifests itself in her tragic aspiration to have blue eyes. But Cholly, Pecola's father, returns home one day and finds Pecola washing dishes. With mixed motives of tenderness and hatred that are fueled by guilt, he rapes her. When Pecola's mother finds her unconscious on the floor, she disbelieves Pecola's story and beats her. Claudia and Frieda find out that Pecola has been impregnated by her father, and unlike the rest of the neighborhood, they want the baby to live. Unfortunately, Pecola's baby dies when it is born prematurely. Cholly rapes Pecola a second time, runs away and dies in a workhouse. Pecola goes mad, believing that her cherished wish has been fulfilled and that she has the bluest eyes. The narrative is told from a third person

Kpohoue, F. (2018). The black community portrayal in toni morrison's the bluest eye (1970), sula (1973) and song of solomon (1977). International Journal of Linguistics, Literature and Culture, 4(5), 20-30. 
omniscient perspective by a neighbor, Claudia MacTeer, who relates the heartbreaking story of Pecola's upbringing as well as the community's responsibility for her ultimate demise. The novel thus causes the reader to reflect upon participation within the black community and the consequences following any deviations from the established cohesiveness of the black society.

Sula, Morrison's second novel further investigates the repressive white society's influence on the black community and examines the corruptive forces which compel the members of the black society to reject and alienate one of their own people (Morrison, 1997). The life of Sula Peace, while growing up in the black community of Medallion in the 1920s, is shaped by her experiences with family and friends. A strong sense of feminine identity is displayed in this independent young woman and when she returns to Medallion as an adult, she is feared and treated as an outcast because of her refusal to conform to the anticipated norms found in black society. Sula's best friend from childhood, Nel Wright, assumes the traditional role of wife and mother as an adult and yet, risks losing her own identity in the process. Therefore, the focus of Sula is the workings and struggles of the internal black society while it simultaneously centers on an in-depth analysis of the marginalized roles of blacks and women within the black community.

Toni Morrison's third novel is entitled Song of Solomon which is an enchanting and moving narrative depicting the black experience and a quest for black identity. It focuses on the character of Milkman Dead and his inner struggle with his white middle-class image and his African- and Native-American roots. Milkman's father, Macon, promotes materialistic ideals and Milkman seems to inherit these qualities along with a predisposition to treat those around him badly. In contrast, Milkman's aunt, Pilate, has a different set of values which include love, affection, respect, and loyalty. Her care and nurturing contribute to Milkman's eventual search for his racial identity. The first part of the novel takes place in the northern community and depicts Milkman's personal past while the second half of the novel occurs in the southern community and explores his ancestral past. Hence, the novel examines the connection between culture, family, heritage, and identity within the traditions and boundaries of the black community (Morrison, 1969).

\section{Settings}

\section{a) The Bluest Eye}

Following the initial psychological backdrop of the novel, the reader finds that The Bluest Eye takes place in Morrison's hometown of Lorain, Ohio from 1940 to 1941. Lorain is known for its steel mills and shipyards and is located on Lake Erie. In the novel, the black community of Lorain is separated from the upper-class white community, also known as Lake Shore Park, a place where blacks are not permitted unless they are employed by a white family. This further emphasizes the perspective that the boundaries of black society are set and defined by the dominant white community. Claudia and Frieda MacTeer go in search of Pecola at Lake Shore Park where Pecola's mother Pauline works for a white family, known as the Fishers. "The lakefront houses were the loveliest. Garden furniture, ornaments, windows like shiny eyeglasses... [the] sky was always blue" (Morrison, The Bluest Eye, 84). The girls are thus subliminally testing the white geographical boundaries. However, their stay is short-lived as Pauline is furious at Pecola for tipping over a pan of blueberry cobbler, "Crazy fool...my floor, mess...look what you....work...get on out...her words were hotter and darker than the smoking berries and we backed away in dread" (Morrison, The Bluest Eye, 87). As the novel progresses, Morrison shows that there are always devastating consequences when the boundaries of racism are tested.

Unlike the black communities in Song of Solomon and Sula, Lorain in The Bluest Eye is marked by blatant differences in the economic standing of its members. There are middle-class families such as the Peals and the characters of Geraldine and her son Louis Junior; the lower-middle class Mr. Henry Washington and the MacTeers; and finally the lower class Breedloves. These differences exert pressure on the members of the black society and its future and are displayed in the attitudes of the people towards one another. When Geraldine arrives home to see Pecola in her house she "saw the dirty torn dress, the plants sticking out on her head...the cheap soles, the soiled socks...the safety pin holding the hem of the dress up...She had seen this girl all of her life...they were everywhere...Get out, you nasty little black bitch. Get out of my house" (Morrison, The Bluest Eye, 75). 
b) Sula

According to Cynthia Davis' essay, Self, Society, and Myth in Toni Morrison's Fiction, “All of Morrison's characters exist in a world defined by its blackness and by the surrounding white society that both violates and denies it" (Davis 27). The setting for Sula is a small town in Ohio, located on a hillside known as "Bottom" from 1919 to 1965 just after World War I. Here again is evidence of the oppressive white society manipulating and mistreating the black community as a white slave owner promises his slave fertile "bottom" land as well as his freedom. However, the slave is deceived into believing that the land on the hillside is "rich and fertile...the bottom of heaven [and is] the best land there is" (Morrison, Sula, 5). The white community establishes itself in the rich and fertile valley while the black community is forced to live on the boundary, or margin, of the white society. Nevertheless, and despite this "nigger joke" (Morrison, Sula, 4), the black community identifies with the designated area, which leads to their acceptance of and consent to live in a degraded situation, "The black people watching her [dancing] would laugh and rub their knees, and it would be easy for the valley men to hear the laughter and not notice the adult pain that rested somewhere under the eyelids, somewhere under their head rags and soft felt hats, somewhere in the palm of the hand somewhere behind the frayed lapels, somewhere in the sinew's curve" (Morrison, Sula 4). Morrison baits the reader with binary opposites as she continues to play with the geographical location of "Bottom" being the hillside area instead of the lower fertile valley; "Bottom" as the less advantageous place to live both for social and economic reasons and yet, which becomes an attractive area for the white community in the 1960s as ironically; the community of "Bottom" is turned into the Medallion City Golf Course which is not located on the flat valley, but rather on a hilly area of land where "the soil slid down and ...the wind lingered" (Morrison, Sula 5). Finally, Bottom is not a recognized municipality in itself, but has boundaries which are defined by the white society of Medallion and according to Morrison, “it wasn’t a town anyway: just a neighborhood” (Morrison, Sula 4).

\section{c) Song of Solomon}

In terms of both time and place, setting plays a key role in Song of Solomon. Although the novel spans approximately a hundred years, documenting three generations of the Dead family's history, it focuses on Milkman's life from birth to age 32. The novel begins in 1931 and ends around 1963. Thus it encompasses two major movements in African-American history: the Harlem Renaissance (1917-35) and the Civil Rights movement (195570s). The year 1931 marks the pinnacle of the Harlem Renaissance, a literary movement heralded as a golden age of black art in the United States. It also marks the rise of the "New Negro," an articulate, sophisticated bourgeois class of intellectual blacks immersed in cultural and aesthetic pursuits, convinced that their literary and artistic achievements would elevate their social and political status in American society by demonstrating to whites that Negroes are not inferior human beings. Ironically, the phrase "New Negro," coined by Alain Locke (1886-1954), the first African-American Rhodes scholar, was rejected by black writers such as Langston Hughes, who believed that authentic artistic expression had its roots in the real-life experiences of "common folk." As Hughes observed, "The ordinary Negroes hadn't heard of the Negro Renaissance. And if they had, it hadn't raised their wages any."

Song of Solomon's physical setting is the Midwest, which, as Morrison notes, "is neither ghetto nor plantation." Geographically, it moves from an unnamed town in Michigan (surely Detroit) to the fictional town of Shalimar, Virginia. Culturally, the novel's setting moves from the industrial North, heavily influenced by the materialistic values and traditions of white society, to the rural South, steeped in traditional values and nurtured by a strong sense of history. Along the way, it takes us — via the characters' memories or actual wanderings — to a variety of U.S. cities and towns: Macon, Georgia; Birmingham, Alabama; Danville, Pennsylvania; Shalimar, Virginia; and Jacksonville, Florida. As Milkman sets out to discover his inheritance, the setting shifts from the North (Michigan) to the South (the fictional town of Shalimar, Virginia). This shift from North to South presents a sharp contrast between the contemporary black northern community and the traditional black southern community. It also reverses the traditional freedom trail of enslaved Africans since Milkman finds freedom not by escaping to the North but by returning to the South. Upon his arrival in Shalimar, Milkman becomes acutely aware of his estrangement and alienation from his cultural roots. By participating in the initiation rituals thrust upon him by the men of Shalimar, by listening to the children sing Solomon's song, and by ridding himself of the mental shackles that bind him to the distorted sense of white, capitalist values espoused by his father, Milkman finally learns the meaning of love and the value of history and tradition. The novel begins and ends with scenes of flight. It moves from the present to the past, from the North to the South, from innocence to experience, from ignorance to wisdom. Like Ralph Ellison's Invisible Man, Song of Solomon focuses on the individual's need to achieve self-knowledge, identity, and visibility as a

Kpohoue, F. (2018). The black community portrayal in toni morrison's the bluest eye (1970), sula (1973) and song of solomon (1977). International Journal of Linguistics, Literature and Culture, 4(5), 20-30.

https://doi.org/10.21744/ijllc.v4n5.289 
complex, real human being. Because Milkman cannot be confined by the boundaries of the community, the movement is outward rather than circular, from Milkman's personal perspective to the black community, to the community at large.

The setting in Song of Solomon should not be limited to the South (the fictional town of Shalimar, Virginia), the idea behind Morrison's decision to refer to the traditional Song of Solomon as the title of her novel goes beyond the limits of America. The South, in the context of America, symbolizes the very place of the Blacks. But Africa, like the mythical song mentions, is the origin of the Blacks where their identity is hidden. They don't know the actual location in Africa but they are determined to discover it and get it back. In fact, the Myth of the Flying Africans is based on a Yoruba folktale that originated among African storytellers and was brought to the United States by free Africans sold as slaves. The story, which centers on a witch doctor or conjures man who empowers enslaved Africans to fly back to Africa, became popular among slaves on the isolated Sea Islands off the coasts of Georgia and South Carolina; for them, the story symbolized a means of escaping the cruelties of slavery.

Originally titled "All God's Chillun Had Wings," the story was first recorded in Drums and Shadows: Survival Studies among the Georgia Coastal Negroes, a book produced in the early 1900s by the Federal Writers' Project, an organization committed to, among its other projects, documenting the stories of African Americans that had been passed down to them by their ancestors, many of whom had been slaves. The story also appeared in The Book of Negro Folklore, a collection of folktales compiled by Langston Hughes and Arna Bontemps, two African-American writers best known for their works published during New York's famous Harlem Renaissance (1915-35). A revised, contemporary version of the story, "People Who Could Fly," appears in Julius Lester's Black Folktales, published in 1969. With its powerful imagery of overcoming and transcending the societal limits of race, sex, and class, flying is a central, symbolic element that reverberates throughout the novel. Song of Solomon alludes to numerous flights that highlight historical events or symbolize pivotal points in the characters' development. In an interview with Thomas Leclair, published in The New Republic ${ }^{\circ} 184$ in 1981, Toni Morrison gives the following reply to this question: How do you conceive of your function as a writer? :

I write what I have recently begun to call village literature, fiction that is real for the village, for the tribe. Peasant literature
for my people, which is necessary and legitimate but which also, allows me to get in touch with all sorts of people. I think
long and carefully about what my novels ought to do. They should clarify the roles that have become obscured; they ought
to identify those things in the past that are useful and those things that are not, and they ought to give nourishment.

What Toni Morrison regards here a "village" could well be a synecdoche for Africa, being also understood the metonymic presence of that continent and the myth of origins it represents every time the South or slavery is alluded to in her books. Through Toni Morrison's novels, it is noticeable that she regards Africa as the land which fed and framed her imagination, the South as a locus of heterogeneous cultures remains meaningfully connected to the 'place' in her fictitious world. One can posit here that the South, as it appears in American history and in linguistic decorum, is fundamental although not exclusively African in most of its cultural manifestations, especially as referenced in Toni Morrison's literary works. In that respect, the presence of Africa, being predominantly felt in the part the past plays in her stories, is implied in situations where 'place' is examined through a few myths which to a certain extent, reflect Toni Morrison's attempt to reconnect with the experience of her people, the African American community at large. In talking about the life and experience of her community, she is undoubtedly contributing greatly to educating her group as well as the 'other', the 'white community' to be more precise against stereotypes and biases readily available to ignorant people.

The presence of Africa is fully justified by the strong ties Toni Morrison has with her community. Her works seem to address the lives of African American people in different historical periods. Toni Morrison sees herself as an agent in the empowerment of her people through the rediscovery of their history. Therefore, no doubt, that her focus be historic and her goal the rediscovery of other African past, lost through slavery and perhaps irretrievable except as she does, through myths. And then only at the risk of life and sanity. Her link with Africa, as revealed by the connections we have already mentioned, results from her early exposure to the literature from that continent. She read Camara Laye, Chicaya U. Tamsi. She is impressed by Chinua Achebe with whom she shares similar approaches when revisiting the African past, the disruptive forces of domination and identity transformation. Yet, Toni Morrison has never tried to visit the continent of her origins. Africa appears hence to explain her heritage and all the values that nurtured her community. As an advocate of integration in the American society, Africa is a central relic she uses to reclaim the validity of her origins without compromising her will to be like most American citizens, a person turned towards the future. However, Morrison has a clear understanding that her future is in control once 
she has a firm grip on her past, in other words, once she can make adequate use of her African heritage to bring to the global American culture.

\title{
3.2 Interactions between the black community and the white community that borders it
}

In the novels of Toni Morrison, the black community is ghettoized, segregated, persecuted and viciously outlawed from all avenues of decency, hope, progress, and livelihood. The black community borders the white one just to highlight the sharp contrast existing between the two groups. In Song of Solomon, the reader is absorbed into the black community, an entity unto itself, but yet never far removed from the white world. The first pages of the novel describe "Not Doctor Street" and "No Mercy Hospital". These names are used within the African-American community but are unofficial and not recognized by the white city rulers who instead identify them as Mains Avenue and Mercy Hospital. This type of separation is visible in Sula and is a part of every scene in the novel, with every aspect of the novel expressing some color of racism. The incidents in the novel are presented based on the life of the black community of the Bottom, which itself was established on a racist act. The Bottom was originally founded because an African American slave was coined by a White slave owner into believing that the location of the town will be profitable. However, as with anything planted in the poor soil in the Bottom, the African American community struggles to survive. In the prologue, for example, the reader is informed that the hills on which the black neighborhood is situated were once considered worthless land. However, when the whites realized the potential of this land, it suddenly became valuable, they began buying the land, and the blacks were forced to move down into the valley. In fact, the Bottom, according to the whites in Medallion is not important at all, it is a mere neighborhood:

\begin{abstract}
There will be nothing left of the Bottom (the footbridge that crossed the river is already gone), but perhaps it is just as well, since it wasn't a town anyway: just a neighborhood where on quiet days people in valley houses could hear singing sometimes, banjos sometimes, and, if a valley man happened to have business up in those hills--collecting rent or insurance payments--he might see a dark woman in a flowered dress doing a bit of cakewalk, a bit of black bottom, a bit of "messing around" to the lively notes of a mouth organ. (Sula, pp. 3-4)
\end{abstract}

The black community, not only is underrated but also minimized by the white; black people living in are subjugated to discrimination, segregation, and humiliation. Jude Greene in Sula is an illustration. After attempting vainly to get a manly job building a new road in Medallion, Jude understands that neither he, nor the other black men from the Bottom will ever get hired. "[I]t was after he stood in lines for six days running and saw the gang boss pick out thinarmed white boys from the Virginia hills and the bull-necked Greeks and Italians and heard over and over, Nothing else today. Come back tomorrow, that he got the message" (Sula, p. 82)... Blacks are a victim of the hatred from the Whites who institutionalized this system made to limit the movement of the Blacks. White people are free to go wherever they want, free to do whatever they like, Blacks are not. Returning by train to New Orleans for her grandmother's funeral, Helene realizes immediately that she has accidentally stepped over the line that separates the two races, she has entered incautiously a train marked "Colored Only" but was rejected by the white conductor in the following sequence:

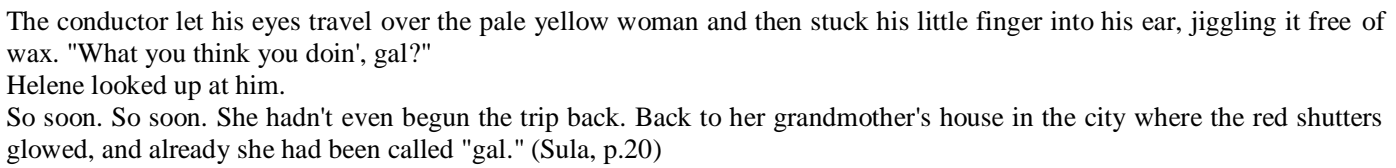

Helene has grown up in New Orleans, she knows the dangers of breaking Jim Crow laws, the mandates that segregated white society from black.

As Helene Wright and Nel opened the door marked Colored Only, they saw a white conductor coming toward them $[\ldots]$ :

The conductor let his eyes travel over the pale yellow woman and then stuck his little finger into his ear, jiggling it free of wax.

What you think you doin' gal?

$[\ldots]$ What was you diin' back in there? What was you doin' in that coach yonde?

[...] We made a mistake, sir. You see, there was n't no sign .We just got in the wrong car, that's all. Sir.

We don't low no mistakes on this train. Now git your butt on in there. (Sula, p. 21)

Kpohoue, F. (2018). The black community portrayal in toni morrison's the bluest eye (1970), sula (1973) and song of solomon (1977). International Journal of Linguistics, Literature and Culture, 4(5), 20-30. 
Another example of the white society's racist attitudes occurs later in the novel when a white bargeman finds Chicken Little's corpse washed ashore at the river's edge. Annoyed at the inconvenience of having to tote the black child's body to the sheriff, the bargeman reacts as though it is not a human that has been lost. He even believes that the blacks are so savage that they would kill their own children. The narrator states:

\begin{abstract}
A bargeman, poling away from the shore, found Chicken late that afternoon stuck in some rocks and weeds [...] He shook his head in disgust at the kind of parents who would down their own children. When he wondered, will those people ever be anything but animals, fit for nothing but substitutes for mules, only mules didn't kill each other the way niggers did. He dumped Chicken Little into a burlap sack and tossed him next to some egg crates and boxes of wool cloth. (Morrison's Sula, 1973)
\end{abstract}

They have "closed face" and "locked eyes"; even their hatred is internalized, a mere "movement under the skin" (Morrison's Sula, 1973, p. 20). Plum, the beloved son of Eva Peace, returns from war a heroin addict, exasperating his mother with his weakness until she sets him on fire.

Racial discrimination ranges from political oppression to economic disempowerment. Following the relative prosperity of the war, new building projects are planned for Medallion, but they exclude giving work to the black people of the Bottom. The geographic exclusion of the black community is mirrored by an economic exclusion. Morrison in the first pages of the novel describes the relationship between the white community of Medallion and the black people in the Bottom as one of economic inequality. The white men who come to the Bottom are in the business of "collecting rent or insurance payments" (Sula, 1973, P. 4), while the black spoon carvers have been out of work for eight years. The story of how the Bottom describes a new kind of racial oppression is not based on political, but economic disempowerment. The prologue of Sula explains the process:

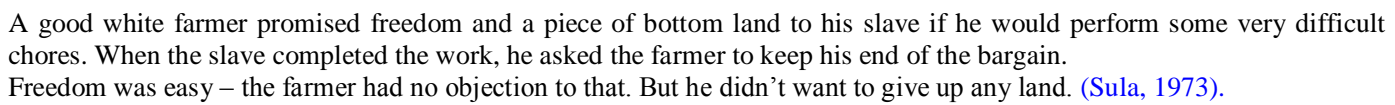

Therefore, the farmer gives his former slave some land up in the hills, reassuring him that "It's the bottom of heaven - best land there is" (Morrison's Sula, 1973). One example of the Bottom's racism is Helene Wright's concern over her daughter Nel's physical features. Although Helene does not want Nel to be as fair skinned as she is, she still forces her daughter to pull her nose in order to make it narrower. "While you sittin' there, honey, go ahead and pull your nose. It hurts, Mamma. Don't you want a nice nose when you grow up?" (Sula, P. 55). And yet Helene herself is the victim of racism, for having grown up in New Orleans, she knows the dangers of breaking Jim Crow laws, the mandates that segregated white society from black. Returning by train to New Orleans for her grandmother's funeral, Helene realizes immediately that she has accidentally stepped over the line that separates the two races when a white conductor catches her in a "WHITES ONLY CAR". The narrator states:

As they opened the door marked COLORED ONLY, they saw a white conductor coming toward them [...] The conductor let his eyes travel over the pale yellow woman and then stuck his little finger into his ear, jiggling it free of wax. What you think you doin' gal?

[...] What was you diin' back in there? What was you doin' in that coach yonde?

[...] We made a mistake, sir. You see, there was n't no sign .We just got in the wrong car, that's all. Sir. We don't low no mistakes on this train. Now git your butt on in there. (Sula, pp.20-21)

Another example of the white society's racist attitudes occurs later in the novel when a white bargeman finds Chicken Little's corpse washed ashore at the river's edge. Annoyed at the inconvenience of having to tote the black child's body to the sheriff, the bargeman reacts as though it is not a human that has been lost. He even believes that the blacks are so savage that they would kill their own children. The narrator states:

\footnotetext{
A bargeman, poling away from the shore, found Chicken late that afternoon stuck in some rocks and weeds [...] He shook his head in disgust at the kind of parents who would down their own children. When he wondered, will those people ever be anything but animals, fit for nothing but substitutes for mules, only mules didn't kill each other the way niggers did. He dumped Chicken Little into a burlap sack and tossed him next to some egg crates and boxes of wool cloth. (Sula, 62)
}

In Song of Solomon, Toni Morrison has presented the grotesque system of racism in her novel Song of Solomon. Almost all the characters in the Song of Solomon are black. The few white characters represent violence and wrongdoing. From the novel onset, the grotesque system of racism is present in the following words: "Not Doctor Street" and "No Mercy Hospital" itself tells us a lot about the social condition. People call the hospital "No Mercy 
Hospital" because it does not admit Blacks. Thus, Morrison begins her novel with the central issue of the novel that is racism. Guitar, Milkman's friend has also a very cruel past. His father has died in front of him in a saw-mill where he was working. The sawmill owner has tried to hide his mistake by giving him few candies. The knowledge that his father has been died because of the white employer's negligence makes Guitar especially sensitive to the injustices perpetrated against Blacks. Guitar responds to whiteness by despising it as thoroughly as whites despise him. Ever since his father was killed in a white-owned sawmill accident, he has refused to accept any sympathy from the white community; on the contrary, he regards all white people, beginning with the man who owned the sawmill, as complicit in the murder of black people. Milkman comes to realize that Guitar, along with his organization, the Seven Days, is responsible for murdering white people in retaliation for black murders in the area. Though most of the white people he kills weren't immediately involved in crimes against black people, Guitar nonetheless considers them racists who deserve to die. Ironically Guitar's monolithic, unsympathetic attitude toward whites is itself a form of race-based prejudice. Morrison's choice of names for her characters in itself indicates the racial discrimination. She wants to give new names to the Blacks and thus introduces names like "Milkman," "Railroad Tommy," "Hospital Tommy," "Empire State" etc.

In The Bluest Eye, Toni Morrison has created two thoroughly racialized communities. Both communities are crippled by racism but in different ways. The Bluest Eye Morrison has created a dualistic tale of the oppressors and the oppressed. The novel illustrates how the racism which exists within the African American community can be seen as an effect of the oppression and racism its members have been subjected to by whites. The racism, oppression, and marginalization have corroded the character's self-esteem and sense of self-worth. Most of the AfricanAmericans portrayed in the book feel contempt for their own blackness. Pauline Breedlove is Pecola's mother. The visit of her husband at her white household workplace is dramatic because that white woman, her employer, turns red when she sees him. This visit is one of her sad memories of racism: her white employer compels her to choose either between her work and her husband: "She said she would let me stay if I left him. I thought about that. But later on, it didn't seem any too bright for a black woman to leave a black man for a white woman. She didn't give me the eleven dollars she owed me, neither. That hurt bad" (Morrison, 1982, p.369). Here, Pauline is economically exploited on the basis of her subordinate race and oppressed gender. The fact that she is compelled to choose between her husband and her work represents a state in which the black woman is seen as an economic slave by the dominant white society. The case is not limited to the women, it is a whole system set by the whites to submit blacks in order to take profit of their effort to meet their economic needs. The practice is both physical and psychological. Pecola would never think she is ugly if she could be aware that beauty standard was imaginative and aimed at working to show that the white race is a superior one.

\section{Conclusion}

The setting pattern used by Toni Morrison in her novels and mainly in The Bluest Eye, Sula and Song of Solomon is a strategy to paint injustice, inequality, and hatred organized by the whites. The black communities in the three novels portray the conditions of Blacks in America after emancipation. The description of the black communities is a technique likely to create a type of revolt and desire to fight the injustice and inequality prevailing in this part of the whole community. Blacks are not slaves anymore, they are American citizens but they live differently in the same country. Toni Morrison throughout her fiction has constantly taken a social and community leader stance, the one who guides the steps of her people in search it's real and true societal personality and identity. The 'All men are created equal' concept that characterizes the American democracy seems not to be extended to the black community. Toni Morrison has willfully decided to shed light to this dark and gloomy part of the American society to show that the torch of liberty and equality is not strong enough to illuminate all the different fragments of the American society.

\section{Conflict of interest statement and funding sources}

The authors declared that he has no competing interest. The study was financed by the author.

Statement of authorship

The author has a responsibility for the conception and design of the study. The author has approved the final article.

Kpohoue, F. (2018). The black community portrayal in toni morrison's the bluest eye (1970), sula (1973) and song of solomon (1977). International Journal of Linguistics, Literature and Culture, 4(5), 20-30. 
Acknowledgments

The author thanks to the reviewer, editor of the International Journal of Linguistics, Literature, and Culture for their support, valuable time, and advice. 


\section{References}

McKay, S. L., \& McKay, S. (1993). Agendas for second language literacy. Cambridge University Press.

Morrison, T. (1982). Sula. 1973. New York: Plume, 76.

Morrison, T. (1993). Jazz. 1992. New York: Plume.

Morrison, T. (1994). The Bluest Eye. 1970. New York: Holt, Rinehart and Winston.

Morrison, T. (2004). Love. London: Vintage.

Morrison, T. (2007). The dancing mind. Vintage.

Morrison, T. (2009). The Nobel lecture in literature, 1993. Knopf.

Morrison, T. (2009). The Nobel lecture in literature, 1993. Knopf.

Morrison, T., \& Price, R. (1978). Song of Solomon (1977).

Morrison, Toni. Beloved. 1987. New York: Plume, Penguin book. 1988.

Kpohoue, F. (2018). The black community portrayal in toni morrison's the bluest eye (1970), sula (1973) and song of solomon (1977). International Journal of Linguistics, Literature and Culture, 4(5), 20-30. 


\section{Biography of Author}

Presently Head of the English Department of the Faculty of Letters, Languages, Arts,
and Communication (FLLAC), University of Abomey-Calavi (UAC), Ferdinand
KPOHOUE holds a Doctorate degree in American Studies since 2012 from the same
University. He is a Senior Lecturer of American Literature and Civilization. Dr.
Kpohoue is a true bilingual scholar, conversant and fluent in English and French. His
previous research works are published in those two languages in the field of American
Literature and Civilization with a special focus on Slavery and African-Americans'
history, identity, evolution, and literature both in national and international journals.
Email: ferdinandkpo@yahoo.fr

